\title{
Nutritional Value of Guajillo as a Component of Male White-Tailed Deer Diets
}

\author{
Tyler A. Campbell ${ }^{1}$ and David G. Hewitt ${ }^{2}$ \\ Authors are ${ }^{1}$ Research Associate, Warnell School of Forest Resources, University of Georgia, Athens, GA 30602; and \\ ${ }^{2}$ Associate Professor, Caesar Kleberg Wildlife Research Institute, Texas AひM University, MSC 218, 700 University Boulevard, \\ Kingsville, TX 78363. At the time of research, Campbell was Graduate Research Assistant, Caesar Kleberg Wildlife \\ Research Institute, Texas A
}

\begin{abstract}
Guajillo (Acacia berlandieri Benth.) is considered a medium- to high-quality forage for both wild and domestic ruminants. However, studies have shown that guajillo contains phenolic amines and alkaloids, and condensed tannins, which may cause toxicosis and reduced fertility, intake, and nutrient digestibility. To examine the nutritional value of guajillo to white-tailed deer (Odocoileus virginianus Zimmermann) more thoroughly, we present a comparison of mixed diets of $0 \%, 25 \%, 50 \%$, and $75 \%$ guajillo in male white-tailed deer. Four in vivo metabolism trials were completed with each diet. Dry matter intake and change in body mass did not differ among diets. Gross and digestible energy intakes did not differ among diets, whereas metabolizable energy intake decreased with increased dietary guajillo concentration. Nitrogen balance and digestibility decreased with increased dietary guajillo concentration. Urinary glucuronic acid excretion increased linearly with increased dietary guajillo concentration. Nitrogen requirements for body growth and antler development were met by diets containing $<60 \%$ guajillo, whereas energy requirements for maintenance and antler growth were met with diets containing $<20 \%$ guajillo. Therefore, concentrations of dietary guajillo $<20 \%$ will support the maintenance of white-tailed deer. The primary function of guajillo may be to facilitate maintenance of adult deer, which have fewer obligatory productive processes than young deer, during periods of drought.
\end{abstract}

\section{Resumen}

El "Guajillo" (Acacia berlandieri Benth.) es considerado como un forraje de calidad media a alta tanto para la fauna silvestre como para los animales domésticos. Sin embargo, estudios reportados han mostrado que el "Guajillo" contiene aminas fenólicas, alcaloides y taninos condensados que pueden causar toxicosis y reducir la fertilidad, consumo y digestibilidad de los nutrientes. Para examinar mas profundamente el valor nutricional del "Guajillo" para el venado cola blanca (Odocoileus virginianus Zimmermann) presentamos una comparación de dietas con 0, 25, 50 y 75\% de "Guajillo" ofrecidas a venados cola blanca machos. Para cada dieta se completaron cuatro ensayos metabólicos in vivo. El consumo de materia seca y los cambios en la masa corporal no difirieron entre las dietas. El consumo de energía bruta y digestible no difirió entre dietas, mientras que el consumo de energía metabolizable el balance de nitrógeno y la digestibilidad disminuyeron al incrementar la concentración de "Guajillo" en la dieta. La excreción urinaria de acido glucuronico se incremento linealmente con el aumento de la concentración del "Guajillo" en la dieta. Los requerimientos de nitrógeno para el crecimiento corporal y el desarrollo de la cornamenta fueron cubiertos con dietas conteniendo $<60 \%$ de "Guajillo", mientras que los requerimientos de energía para mantenimiento y el crecimiento de la cornamenta se satisficieron con dietas con $<20 \%$ de "Guajillo". Por lo tanto concentraciones de "Guajillo"de $<20 \%$ en la dieta sostendrán el mantenimiento del venado cola blanca. La función principal del "Guajillo" puede ser el facilitar el mantenimiento de venados adultos, los cuales tienen menos procesos productivos obligatorios que los venados jóvenes durante los periodos de sequía.

Key Words: Acacia berlandieri, detoxification, glucuronic acid, Odocoileus virginianus

\section{INTRODUCTION}

Research was funded by contributions of the Caesar Kleberg Wildlife Research Institute, the Houston Livestock and Rodeo Association, and the Texas Agricultural Experiment Station-Uvalde.

This is manuscript number 01-111 of the Caesar Kleberg Wildlife Research Institute. Correspondence: Dr Tyler A. Campbell, National Wildlife Research Center, USDA/ APHIS/WS, Texas Field Station, Texas A\&M University-Kingsville, 700 University Blvd, MSC 218, Kingsville, TX 78363. Email: Tyler.A.Campbell@aphis.usda.gov

Manuscript received 5 January 2004; manuscript accepted 6 June 2004
Guajillo (Acacia berlandieri Benth.) is a leguminous shrub or small tree occurring in the Rio Grande Plain of southern Texas and northern Mexico (Vines 1984). It occupies 2.4 million ha in southern Texas alone (Scifres 1980) and is browsed by both wild and domestic ruminants, particularly during periods of extended drought (Varner and Blankenship 1987). Conventionally, guajillo is considered a medium- to high-quality forage for both wild and domestic ruminants because of its high nitrogen $(\mathrm{N})$ content (Varner et al. 1977); under drought 
Table 1. Chemical composition of diets fed to captive male white-tailed deer during July-September 1998 in Kingsville, Texas.

\begin{tabular}{|c|c|c|c|c|}
\hline \multirow[b]{2}{*}{ Nutrient category } & \multicolumn{4}{|c|}{ Percent guajillo in diet ${ }^{1}$} \\
\hline & $0 \%$ & $25 \%$ & $50 \%$ & $75 \%$ \\
\hline Dry matter (\%) & 88.2 & 89.8 & 90.1 & 90.5 \\
\hline Organic matter ( $\%$ dry matter) & 89.3 & 90.0 & 91.5 & 92.4 \\
\hline $\mathrm{N}^{2}$ (\% dry matter) & 4.1 & 3.8 & 3.5 & 3.1 \\
\hline Crude protein ( $\%$ dry matter) & 25.7 & 23.9 & 21.6 & 19.7 \\
\hline Digestible N $\left(\mathrm{g} \cdot 100 \mathrm{~g} \mathrm{feed}^{-1}\right)$ & 3.1 & 2.4 & 1.8 & 1.3 \\
\hline ADF-N (\% dry matter) & 0.12 & 0.22 & 0.27 & 0.30 \\
\hline ADF-N (\% of total nitrogen) & 2.8 & 5.8 & 7.8 & 9.6 \\
\hline Gross energy $\left(\mathrm{kcal} \cdot \mathrm{g}^{-1}\right)$ & 4.4 & 4.5 & 4.6 & 4.8 \\
\hline Digestible energy $\left(\mathrm{kcal} \cdot \mathrm{g}^{-1}\right)$ & 2.7 & 2.5 & 2.2 & 2.0 \\
\hline Metabolizable energy $\left(\mathrm{kcal} \cdot \mathrm{g}^{-1}\right)$ & 2.3 & 2.1 & 1.9 & 1.5 \\
\hline NDF (\% dry matter) & 27.2 & 29.7 & 32.3 & 33.1 \\
\hline Hemicellulose (\% dry matter) & 8.3 & 8.9 & 9.4 & 10.1 \\
\hline Cellulose (\% dry matter) & 16.6 & 13.5 & 12.3 & 10.9 \\
\hline Lignin (\% dry matter) & 3.8 & 6.9 & 10.4 & 11.7 \\
\hline
\end{tabular}

${ }^{1}$ Percent guajillo in diets based on guajillo-to-alfalfa ratios on a dry matter basis.

${ }^{2} \mathrm{~N}$ indicates nitrogen; ADF, acid detergent fiber; NDF, neutral detergent fiber.

conditions guajillo may constitute as much as $37 \%$ of whitetailed deer (Odocoileus virginianus Zimmermann) diets (Hughes 1982; Varner and Blankenship 1987). However, guajillo contains phenolic amines and alkaloids (Camp et al. 1964; Clement et al. 1997), and condensed tannins (Barnes et al. 1991a), which may cause toxicosis and reduced fertility, intake, and nutrient digestibility in ruminants. For example, Nantoumé et al. (2001) fed goats mixed diets containing 0\%, $25 \%, 50 \%$, and $75 \%$ guajillo and observed decreased digestibility of dry matter, organic matter, $\mathrm{N}$, energy, and fiber with increased dietary concentrations of guajillo; they concluded that diets containing guajillo do not meet digestible energy requirements for maintenance. These discoveries bring into question the nutritional value of guajillo as a forage for whitetailed deer.

In vivo investigations of white-tailed deer-guajillo nutritional relationships have been conducted using $100 \%$ guajillo diets (Barnes et al. 1991a, 1991b). These studies are important in understanding seasonal dynamics of passage rates and digestibilities, but may not be applicable to free-ranging herbivores because $100 \%$ guajillo diets have never been documented and would not be expected. This relationship is evidenced by the observation that deer did not perform well on strict guajillo diets (i.e., 1 of 6 study animals went off feed during most feeding trials; Barnes et al. 1991a, 1991b).

Understanding the nutritional dynamics of both wild and domestic ruminants is relevant to the conservation and management of rangelands. To examine the nutritional value of guajillo to deer more thoroughly, we present a comparison of diets containing $0 \%, 25 \%, 50 \%$, and $75 \%$ guajillo fed to male white-tailed deer. Our objectives were to quantify and evaluate the influence of dietary guajillo concentration on dry matter intake; digestibility of energy, $\mathrm{N}$, and fiber; metabolism of $\mathrm{N}$ and energy; and to examine a mode of detoxification used by deer. Previous research suggests elevated detoxification activity among goats fed diets of $75 \%$ guajillo (Nantoumé et al. 2001).
Consequently, we expected similar responses within deer. In addition, we estimate dietary guajillo concentrations at which requirements for maintenance and productive processes in male white-tailed deer are achieved. This information is important to managers charged with stewardship of white-tailed deer, a valuable rangeland commodity.

\section{MATERIALS AND METHODS}

\section{Study Environment and Diets}

We conducted all research in accordance with the guidelines of the Institutional Animal Care and Use Committee at the captive wildlife research facility at Texas A\&M University-Kingsville, located $1.5 \mathrm{~km}$ north of Kingsville, Texas. In June 1998, we placed deer into individual pens $(3.0 \times 3.7 \mathrm{~m})$ where food and water were available ad libitum. We maintained deer on 56A3 Kleberg Custom Deer Feed Hi-P (Purina Mills, Inc, St Louis, $\mathrm{MO}$ ) and provided alfalfa (Medicago sativa L.) hay until the experiment commenced.

We collected guajillo growing in Webb and Duval counties, Texas, from 11 June to 2 July 1998, a period of drought. Only growth from the current year $<1.5 \mathrm{~m}$ in height was collected to reduce the inclusion of forage that would be physically unavailable to deer. We removed herbaceous guajillo stems and leaves with hand clippers and allowed them to air-dry for 5 days $(90 \%$ dry matter). We supplemented guajillo with alfalfa hay because its nutritive value is similar to that of native forbs, it has low secondary plant chemical concentrations, and it required minimal preparation. We ground guajillo and alfalfa with a hammer mill to pass a $1-\mathrm{cm}$ screen. We mixed guajillo and alfalfa forages into 4 diets containing guajillo-to-alfalfa ratios of $0: 100,25: 75,50: 50$, and 75:25 on a dry-matter basis (Table 1). We collected and mixed all diets in accordance with procedures of Nantoumé et al. (2001).

\section{Experimental Design and Feeding Trials}

We completed 4 in vivo metabolism trials in accordance with methods of Nantoumé et al. (2001) on 4 adult ( $\geq 5$ years old) male white-tailed deer in a $4 \times 4$ Latin square design. For each of the 4 trials, 4 deer were assigned randomly to each of the 4 diets such that 1 deer received each diet. For each successive trial, randomization was restricted to ensure that each deer received a diet it had not received previously.

We conducted the 4 metabolism trials from 12 July to 18 September 1998. Trials consisted of a 10-day acclimation period and a 7-day total collection period. We completed the first 5 days of the trial in individual pens $(3.0 \times 3.7 \mathrm{~m})$. We completed the final 12 days of the trial in metabolism crates measuring $1.5 \times 1.5 \times 1.5 \mathrm{~m}$. We obtained deer body mass with an Allflex weighing system (Allflex USA, DFW Airport, TX) during transport to and from the metabolism crates on days 5 and 17 of each trial. Food, a mineral premix (Record Rack $^{\top \mathrm{M}}$ Deer and Game Mineral, Cargill, Inc, Minneapolis, $\mathrm{MN}$ ), and double-distilled water were available ad libitum throughout each trial. We recorded daily orts and food intake on a dry-matter basis.

Feces and urine were collected, quantified, and sampled daily during the collection phase of each trial in accordance with procedures of Hellgren and Pitts (1997). We pooled a 10\% sample of daily fecal excretion by deer and stored it at $-20^{\circ} \mathrm{C}$. 
At the conclusion of the collection period, we dried the composite fecal sample for 24 hours at $50^{\circ} \mathrm{C}$ and ground it with a Wiley mill to pass a $1-\mathrm{mm}$ screen for subsequent chemical analysis. Daily fecal excretion that was not retained for analysis was oven-dried at $100^{\circ} \mathrm{C}$ for 24 hours to determine dry matter. We obtained daily urine $\mathrm{pH}$ readings from each deer. We acidified urine with $150 \mathrm{~mL}$ of $0.1 \mathrm{~N} \mathrm{HCl}$ and a $10 \%$ daily aliquot was pooled by deer and stored at $-20^{\circ} \mathrm{C}$. At the conclusion of the collection period, we thawed and mixed urine, storing a $400-\mathrm{mL}$ sample at $-20^{\circ} \mathrm{C}$ for subsequent chemical analysis, which we adjusted for $\mathrm{HCl}$ dilution. We ground a 200-g sample of each diet for each trial with a Wiley mill to pass a 1-mm screen for subsequent chemical analysis.

\section{Chemical Analyses}

We determined $\mathrm{N}$ content of the feed, feces, and urine with the Kjeldahl procedure. Urinary ammonium $\mathrm{N}$, which provides an index to acid loading (Foley et al. 1995), was determined by the Kjeldahl procedure without the sulfuric acid digestion step (Remington 1990). We determined gross energy of the feed, feces, and urine with a Parr adiabatic bomb calorimeter. Urinary gross energy was determined by adding $1.75 \mathrm{~mL}$ of urine to a compressed cotton ball $(0.5 \mathrm{~g})$, which was then dried overnight at $50^{\circ} \mathrm{C}$. We then completed bomb calorimetry and gross energy of the urine was calculated by subtracting the energy value of the cotton ball from the energy value of the urine-saturated cotton ball.

We conducted detergent analyses (Goering and Van Soest 1970; Mould and Robbins 1981) sequentially on feed and fecal samples with an Ankom ${ }^{200}$ Fiber Analyzer (Ankom Technology, Fairport, NY). We did not add sodium sulfite to the neutral detergent solution. We determined hemicellulose by difference. We determined cellulose by difference following a $\mathrm{H}_{2} \mathrm{SO}_{4}$ treatment. We determined lignin-cutin by difference after ashing the residue. We determined $\mathrm{N}$ in acid detergent fiber (ADF) of feed with the Kjeldahl procedure.

We determined protein precipitation capacity of dietary tannins on pooled diet samples with bovine serum albumin (BSA; Martin and Martin 1982; Robbins et al. 1987). We determined urinary glucuronic acid excretion using a colorimetric procedure (Blumenkrantz and Asboe-Hansen 1973), which we used as an index to detoxification activity (Foley and McArthur 1994).

We calculated $\mathrm{N}$ balance as input minus output (feces plus urine). We expressed $\mathrm{N}$ input, output, and balance as $\mathrm{g} \cdot \mathrm{kg}$ body mass $^{-0.75} \cdot$ day $^{-1}$. We calculated metabolizable energy without inclusion of the gaseous energy losses, and calculated nutrient digestibilities with traditional formulas (Robbins 1993). We conducted $\mathrm{N}$, energy, glucuronic acid, and fiber analyses at the Texas A\&M University-Kingsville Forage Laboratory. We measured protein precipitation capacity at the Texas Agricultural Experiment Station-Uvalde Nutrition Laboratory.

\section{Statistical Analyses and Calculations}

We analyzed digestion trial parameters with a 3-way analysis of variance (SAS Institute, Inc. 1994) without interaction effects in accordance with procedures of Nantoumé et al. (2001). Class variables in the model were diet, trial, and deer. Because a Latin
Table 2. Body mass on days 5 and 17 of the feeding trials, change in body mass, intake of dry matter and water, urine excretion, and apparent dry matter digestibility for captive male white-tailed deer fed 4 diets during July-September 1998 in Kingsville, Texas. Means in a row with different letters were different at $\alpha=0.05 ; n=4$ for all diets.

\begin{tabular}{|c|c|c|c|c|c|c|c|c|}
\hline \multirow[b]{3}{*}{ Nutritional variable } & \multicolumn{8}{|c|}{ Percent guajillo in diet ${ }^{1}$} \\
\hline & \multicolumn{2}{|c|}{$0 \%$} & \multicolumn{2}{|c|}{$25 \%$} & \multicolumn{2}{|l|}{$50 \%$} & \multicolumn{2}{|c|}{$75 \%$} \\
\hline & Mean & SE & Mean & SE & Mean & SE & Mean & SE \\
\hline Day 5 body mass (kg) & $64.1 \mathrm{a}$ & 1.0 & $63.6 \mathrm{a}$ & 0.9 & $64.8 \mathrm{a}$ & 1.6 & $63.2 \mathrm{a}$ & 0.8 \\
\hline Day 17 body mass (kg) & $64.0 \mathrm{a}$ & 1.1 & $64.4 \mathrm{a}$ & 1.1 & $64.5 \mathrm{a}$ & 2.0 & $62.5 \mathrm{a}$ & 0.7 \\
\hline Body mass change $(\mathrm{kg})$ & $-0.1 \mathrm{a}$ & 0.3 & $0.8 \mathrm{a}$ & 0.5 & $-0.3 a$ & 0.4 & $-0.7 a$ & 0.2 \\
\hline \multicolumn{9}{|l|}{ Dry matter intake } \\
\hline$\left(\mathrm{g} \cdot \mathrm{kg}^{-0.75} \cdot \mathrm{day}^{-1}\right)$ & $64.0 \mathrm{a}$ & 3.0 & $67.4 \mathrm{a}$ & 4.7 & $69.5 \mathrm{a}$ & 7.8 & $62.8 \mathrm{a}$ & 7.9 \\
\hline \multicolumn{9}{|l|}{ Water intake } \\
\hline$\left(\mathrm{Wl}, 1 \cdot\right.$ day $\left.^{-1}\right)$ & $6.74 a$ & 0.24 & $6.19 a$ & 0.22 & $5.40 a, b$ & 0.39 & $4.44 b$ & 0.51 \\
\hline \multicolumn{9}{|l|}{ Urine excretion } \\
\hline$\left(\mathrm{UE}, 1 \cdot\right.$ day $\left.^{-1}\right)$ & $2.72 \mathrm{a}$ & 0.20 & $2.42 a, b$ & 0.10 & $1.94 b, c$ & 0.21 & $1.46 \mathrm{c}$ & 0.18 \\
\hline \multicolumn{9}{|l|}{ WI minus } \\
\hline UE $\left(1 \cdot\right.$ day $\left.^{-1}\right)$ & $4.02 \mathrm{a}$ & 0.15 & $3.77 a$ & 0.14 & $3.46 \mathrm{a}$ & 0.21 & $2.98 \mathrm{a}$ & 0.39 \\
\hline \multicolumn{9}{|l|}{ Dry matter } \\
\hline digestibility (\%) & $64.2 \mathrm{a}$ & 1.7 & $56.5 b$ & 1.2 & $49.9 c$ & 0.7 & $44.3 d$ & 0.3 \\
\hline
\end{tabular}

${ }^{1}$ Percent guajillo in diets based on guajillo-to-alfalfa ratios on a dry matter basis.

square design was used, $P$ values generated on row (i.e., trial or blocking factor 1) and column (i.e., deer or blocking factor 2) variables were invalid and not reported (Kuehl 1994). If we detected significant dietary effects, pairwise comparisons were completed with Tukey's honestly significant difference (HSD) test (SAS Institute, Inc 1994). Tukey's HSD controls the Type I error rate on an experiment-wise basis and is highly conservative (Schulman 1992). Statistical significance was determined at $P<0.05$.

We plotted nutrient intake levels as a function of dietary guajillo concentration. Data were subjected to stepwise polynomial regression. Higher order polynomials did not improve the relationship relative to the linear equation, so we reported linear relationships. We used published nutrient requirements to assess how well experimental diets met nutrient requirements. We assumed maintenance energy requirements for free-ranging deer to be $164 \mathrm{kcal} \cdot \mathrm{kg}^{-0.75} \cdot \mathrm{day}^{-1}$ (Robbins 1993, our calculation). We assumed energy requirements for antler growth were $165 \mathrm{kcal} \cdot \mathrm{kg}^{-0.75} \cdot \mathrm{day}^{-1}$ (Robbins 1983 , our calculation). We assumed $\mathrm{N}$ requirements for maintenance and body growth during antler development to be $0.61 \mathrm{~g} \mathrm{~N} \cdot \mathrm{kg}^{-0.75} \cdot \mathrm{day}^{-1}$ and $1.06 \mathrm{~g} \mathrm{~N} \cdot \mathrm{kg}^{-0.75} \cdot \mathrm{day}^{-1}$, respectively (Asleson et al. 1996). We assumed $\mathrm{N}$ requirements for maintenance of yearlings to be $0.77 \mathrm{~g} \mathrm{~N} \cdot \mathrm{kg}^{-0.75} \cdot \mathrm{day}^{-1}$ (Holter et al. 1979).

\section{RESULTS}

White-tailed deer body mass did not differ (all $F_{3,6} \leq 4.42$; $P \geq 0.06$ ) in response to diet (Table 2). With the exception of deer on the $75 \%$ guajillo diet, none of the diets resulted in mass changes significantly different from zero. Daily dry matter intake did not differ $\left(F_{3,6}=0.56 ; P=0.66\right)$ among diets. Dietary differences occurred for daily water intake and urine excretion. Deer decreased water intake $\left(F_{3,6}=11.97\right.$; 
Table 3. Daily energy intake and gross energy (GE) partition for captive male white-tailed deer fed 4 diets during July-September 1998 in Kingsville, Texas. Means in a row with different letters were different at $\alpha=0.05 ; n=4$ for all diets.

\begin{tabular}{|c|c|c|c|c|c|c|c|c|}
\hline \multirow[b]{3}{*}{ Nutritional variable } & \multicolumn{8}{|c|}{ Percent guajillo in diet ${ }^{1}$} \\
\hline & \multicolumn{2}{|c|}{$0 \%$} & \multicolumn{2}{|c|}{$25 \%$} & \multicolumn{2}{|c|}{$50 \%$} & \multicolumn{2}{|c|}{$75 \%$} \\
\hline & Mean & SE & Mean & SE & Mean & SE & Mean & SE \\
\hline GE intake $\left({\left.\mathrm{kcal} \cdot \text { day }^{-1}\right)}^{-1}\right.$ & $6336 a$ & 331 & $6870 a$ & 361 & $7357 a$ & 974 & $6765 a$ & 885 \\
\hline GE intake $\left(\mathrm{kcal} \cdot \mathrm{kg}^{-0.75} \cdot\right.$ day $\left.^{-1}\right)$ & 280a & 12 & $304 a$ & 18 & $321 a$ & 36 & $303 a$ & 38 \\
\hline Digestible energy intake $\left(\mathrm{kcal} \cdot \mathrm{kg}^{-0.75} \cdot\right.$ day $\left.^{-1}\right)$ & $173 a$ & 2 & $164 a$ & 11 & $151 \mathrm{a}$ & 17 & $122 \mathrm{a}$ & 11 \\
\hline \multicolumn{9}{|l|}{ Metabolizable energy intake } \\
\hline$\left(\mathrm{kcal} \cdot \mathrm{kg}^{-0.75} \cdot\right.$ day $\left.^{-1}\right)$ & $146 a$ & 3 & $140 a, b$ & 8 & $131 a, b$ & 15 & $89 \mathrm{~b}$ & 12 \\
\hline Digestible energy coefficient (\%) & $62.1 \mathrm{a}$ & 2.3 & $54.1 a, b$ & 1.9 & $47.3 b, c$ & 1.5 & $40.9 c$ & 2.9 \\
\hline Metabolizable energy coefficient (\%) & $52.4 \mathrm{a}$ & 1.9 & $46.4 a, b$ & 2.3 & $41.1 b, c$ & 2.4 & $30.3 \mathrm{c}$ & 4.7 \\
\hline Urine energy per digestible energy (\%) & $15.4 \mathrm{a}$ & 1.6 & $14.5 \mathrm{a}$ & 1.6 & $13.3 a$ & 2.4 & $25.5 \mathrm{a}$ & 10.6 \\
\hline
\end{tabular}

${ }^{1}$ Percent guajillo in diets based on guajillo-to-alfalfa ratios on a dry matter basis.

$P=0.006)$ and urine excretion $\left(F_{3,6}=29.09 ; P=0.001\right)$ with increased dietary guajillo. Apparent dry matter digestibility decreased $\left(F_{3,6}=108.1 ; P<0.001\right)$ with increased dietary guajillo.

Gross and digestible energy intakes did not differ (all $F_{3,6} \leq 3.98 ; P \geq 0.07$ ) among diets (Table 3). Differences occurred in metabolizable energy intake $\left(F_{3,6}=5.7\right.$; $P=0.03$ ) among diets. Metabolizable energy intake decreased with increased dietary guajillo. Digestible and metabolizable energy coefficients decreased (all $F_{3,6} \geq 16.89 ; P \leq 0.003$ ) with increased dietary guajillo. No differences occurred among diets for urinary energy excreted per digestible energy intake.

Decreases in dietary percent $\mathrm{N}$ and digestible $\mathrm{N}$ with increased dietary guajillo (Table 1 ) contributed to decreased $\mathrm{N}$ intake $\left(F_{3,6}=6.34 ; P=0.03\right)$, urinary $\mathrm{N}\left(F_{3,6}=98.08 ; P<0.001\right)$,

Table 4. Nitrogen ( $\mathrm{N}$ ) balance data, digestible dry matter and $\mathrm{N}$ intake, urinary $\mathrm{N}$ per digestible $\mathrm{N}$ intake, apparent $\mathrm{N}$ digestibility, and adjusted $\mathrm{N}$ digestibility (without ADF-N in feed) for captive male white-tailed deer fed 4 diets during July-September 1998 in Kingsville, Texas. Means in a row with different letters were different at $\alpha=0.05 ; n=4$ for all diets.

\begin{tabular}{|c|c|c|c|c|c|c|}
\hline \multirow[b]{3}{*}{ Nutritional variable } & \multicolumn{6}{|c|}{ Percent guajillo in diet ${ }^{1}$} \\
\hline & $0 \%$ & \multicolumn{2}{|c|}{$25 \%$} & \multicolumn{2}{|c|}{$50 \%$} & $75 \%$ \\
\hline & Mean SE & Mean & SE & Mean & SE & Mean SE \\
\hline $\mathrm{N}$ intake $\left(\mathrm{g} \cdot \mathrm{kg}^{-0.75} \cdot\right.$ day $\left.^{-1}\right)$ & 2.63a 0.13 & $2.57 a$ & 0.15 & $2.39 a, b$ & 0.26 & $1.98 b 0.26$ \\
\hline \multicolumn{7}{|l|}{ N loss: feces } \\
\hline$\left(\mathrm{g} \cdot \mathrm{kg}^{-0.75} \cdot \mathrm{day}^{-1}\right)$ & $0.63 a 0.05$ & $0.94 a, b$ & 0.08 & $1.17 \mathrm{~b}$ & 0.14 & $+1.18 b 0.15$ \\
\hline \multicolumn{7}{|l|}{ N loss: urine } \\
\hline$\left(\mathrm{g} \cdot \mathrm{kg}^{-0.75} \cdot \mathrm{day}^{-1}\right)$ & $1.20 \mathrm{a} 0.04$ & $1.01 \mathrm{~b}$ & 0.01 & $0.77 \mathrm{c}$ & 0.05 & $0.57 \mathrm{~d} 0.05$ \\
\hline \multicolumn{7}{|l|}{$\mathrm{N}$ balance } \\
\hline$\left(\mathrm{g} \cdot \mathrm{kg}^{-0.75} \cdot \mathrm{day}^{-1}\right)$ & $0.80 \mathrm{a} 0.06$ & $0.62 b$ & 0.08 & $0.46 c$ & 0.08 & $30.24 d 0.07$ \\
\hline \multicolumn{7}{|l|}{ Digestible dry matter } \\
\hline intake $\left(\mathrm{g} \cdot \mathrm{kg}^{-0.75} \cdot\right.$ day $\left.^{-1}\right)$ & $41.0 \mathrm{a} \quad 1.4$ & $37.9 \mathrm{a}$ & 2.0 & $34.5 a, b$ & 3.4 & $27.8 \mathrm{~b} \quad 3.4$ \\
\hline Digestible N intake (DNI) & 1.99a 0.09 & $1.63 b$ & 0.07 & $1.22 \mathrm{C}$ & 0.12 & $0.81 \mathrm{~d} 0.12$ \\
\hline Urinary N per DNI (\%) & $60.1 \mathrm{a} \quad 1.7$ & $62.5 \mathrm{a}$ & 3.1 & $63.5 a$ & 3.1 & $72.6 \mathrm{~b} \quad 4.5$ \\
\hline N digestibility (ND, \%) & $75.9 \mathrm{a} \quad 0.7$ & $63.7 \mathrm{~b}$ & 1.4 & $51.3 \mathrm{c}$ & 1.1 & $40.5 d \quad 1.7$ \\
\hline Adjusted ND (AND, \%) & $75.2 \mathrm{a} \quad 0.7$ & $61.5 b$ & 1.6 & $47.2 \mathrm{c}$ & 1.1 & $34.2 \mathrm{~d} \quad 1.9$ \\
\hline ND - ND (\%) & $0.7 a \quad 0.0$ & $2.2 b$ & 0.1 & $4.1 \mathrm{C}$ & 0.1 & $6.3 d \quad 0.3$ \\
\hline
\end{tabular}

${ }^{1}$ Percent guajillo in diets based on guajillo-to-alfalfa ratios on a dry matter basis. and $\mathrm{N}$ balance $\left(F_{3,6}=63.62 ; P<0.001\right.$; Table 4$)$. Fecal $\mathrm{N}$ increased $\left(F_{3,6}=8.88 ; P=0.01\right)$ with increased dietary guajillo. Apparent $\mathrm{N}$ digestibility decreased $\left(F_{3,6}=130.54\right.$; $P<0.001)$ with increased dietary guajillo. The percentage of digestible $\mathrm{N}$ intake excreted in the urine increased $\left(F_{3,6}=9.01\right.$; $P=0.01$ ) with increased guajillo in the diet.

Protein precipitation capacity of dietary tannins for $0 \%$, $25 \%, 50 \%$, and $75 \%$ guajillo diets was $0.001,0.094,0.166$, and $0.244 \mathrm{mg} \mathrm{BSA} \cdot \mathrm{mg}$ feed $^{-1}$, respectively. Urine $\mathrm{pH}$ and urinary ammonium $\mathrm{N}$ did not differ $\left(\right.$ all $F_{3,6} \leq 1.72 ; P \geq 0.23$ ) among diets (Table 5). Urinary glucuronic acid excretion increased with increased dietary guajillo (all $F_{3,6} \geq 14.36$; $P \leq 0.004)$.

Energy requirements for maintenance and antler growth were met with diets containing approximately $<20 \%$ guajillo (Fig. 1). Nitrogen requirements for maintenance of adult males and yearlings were met by all of the experimental diets (Fig. 2). Nitrogen requirements for body growth and antler development were met by diets containing approximately $<60 \%$ guajillo.

\section{DISCUSSION AND CONCLUSIONS}

Fluctuations in deer body mass were minimal during trials. Change in body mass, which approached significance $\left(F_{3,6}=4.42 ; P=0.06\right)$, differed from zero only for deer fed the $75 \%$ guajillo diet. Despite a reduction in available energy with increased dietary guajillo (Table 1), deer did not increase dry matter intake to meet energy demands. This observation suggests that additional factors, such as plant chemical detoxification, limit guajillo consumption in deer. In addition to tannins, guajillo contains many other plant chemicals (Clement et al. 1997) that are absorbed and must be detoxified.

Feeding white-tailed deer diets of $100 \%$ guajillo in late summer, Barnes et al. (1991a) reported dry matter intake rates of $46.0 \mathrm{~g} \cdot \mathrm{kg}^{-0.75} \cdot \mathrm{day}^{-1}$ (our calculation). Deer fed diets of $75 \%$ guajillo in our study consumed $47.1 \mathrm{~g} \cdot \mathrm{kg}^{-0.75} \cdot \mathrm{day}^{-1}$ of guajillo (in addition to $15.7 \mathrm{~g} \cdot \mathrm{kg}^{-0.75} \cdot \mathrm{day}^{-1}$ of alfalfa). Our data agree closely with the amount of guajillo consumed by deer fed $100 \%$ guajillo diets (Barnes et al. 1991a) and suggest that guajillo intake rates near $47.0 \mathrm{~g} \cdot \mathrm{kg}^{-0.75} \cdot \mathrm{day}^{-1}$ represent an upper limit to the amount of guajillo that deer can consume. 
Table 5. Urine $\mathrm{pH}$, nitrogen (N) concentration, ammonium nitrogen, and glucuronic acid excretion for captive male white-tailed deer fed 4 diets during July-September 1998 in Kingsville, Texas. Means in a row with different letters were different at $\alpha=0.05 ; n=4$ for all diets.

\begin{tabular}{|c|c|c|c|c|c|c|c|c|}
\hline \multirow[b]{3}{*}{ Urinary variable } & \multicolumn{8}{|c|}{ Percent guajillo in $\operatorname{diet}^{1}$} \\
\hline & \multicolumn{2}{|c|}{$0 \%$} & \multicolumn{2}{|c|}{$25 \%$} & \multicolumn{2}{|c|}{$50 \%$} & \multicolumn{2}{|c|}{$75 \%$} \\
\hline & Mean & SE & Mean & SE & Mean & SE & Means & SE \\
\hline Urine $\mathrm{pH}$ & $8.08 \mathrm{a}$ & 0.09 & $7.97 \mathrm{a}$ & 0.06 & $7.99 \mathrm{a}$ & 0.16 & $7.96 \mathrm{a}$ & 0.07 \\
\hline \multicolumn{9}{|l|}{ Urinary N } \\
\hline$\left(\mathrm{mg} \mathrm{N} \cdot \mathrm{mL}^{-1}\right)$ & $10.06 a$ & 0.51 & $9.58 \mathrm{a}$ & 0.56 & $9.13 \mathrm{a}$ & 0.43 & $8.81 a$ & 0.52 \\
\hline \multicolumn{9}{|l|}{ Ammonium N } \\
\hline$\left(\mathrm{mg} \cdot \mathrm{kg}^{-0.75} \cdot\right.$ day $\left.^{-1}\right)$ & $62.9 \mathrm{a}$ & 5.0 & $58.5 a$ & 16.4 & $37.5 \mathrm{a}$ & 3.9 & $31.6 a$ & 4.7 \\
\hline \multicolumn{9}{|l|}{ Ammonium N } \\
\hline (\% urinary $\mathrm{N}$ ) & $5.2 \mathrm{a}$ & 0.3 & $5.8 \mathrm{a}$ & 1.7 & $4.8 \mathrm{a}$ & 0.2 & $5.5 \mathrm{a}$ & 0.6 \\
\hline \multicolumn{9}{|l|}{ Glucuronic acid } \\
\hline$\left(\mathrm{mmol} \cdot \mathrm{kg}^{-0.75} \cdot \mathrm{day}^{-1}\right)$ & $0.29 a$ & 0.11 & $0.64 a$ & 0.19 & $1.24 b$ & 0.13 & $1.64 \mathrm{c}$ & 0.06 \\
\hline \multicolumn{9}{|c|}{ Glucuronic acid } \\
\hline$\left(\mathrm{mg} \cdot \mathrm{g}\right.$ food $\left.^{-1}\right)$ & $0.85 a$ & 0.29 & $2.00 \mathrm{a}, \mathrm{b}$ & 0.78 & $3.51 \mathrm{~b}, \mathrm{c}$ & 0.78 & $5.29 \mathrm{c}$ & 0.63 \\
\hline
\end{tabular}

${ }^{1}$ Percent guajillo in diets based on guajillo-to-alfalfa ratios on a dry matter basis.

We propose that a chemical threshold limits guajillo consumption, which is important when deer are faced with energy deficits because they physiologically cannot eat more guajillo to compensate for energy shortages.

Gross and digestible energy intake did not differ among diets; however, energy was used less efficiently by deer fed diets higher in guajillo, as indicated by differences in digestible and metabolizable energy coefficients. Energy-rich plant chemicals, such as terpenoids and volatile oils, are readily absorbed and excreted in the urine (Foley and McArthur 1994). Because urinary energy expressed as a percentage of digestible energy did not vary by diet, it is unlikely that large amounts of these energy-rich plant chemicals were absorbed and metabolized by deer.

Range managers generally consider guajillo a high-quality forage because of its elevated $\mathrm{N}$ content and corresponding crude protein values. However, we observed that both $\mathrm{N}$ intake and apparent $\mathrm{N}$ digestibility were decreased with increased dietary guajillo. Apparent $\mathrm{N}$ digestibility of guajillo, as with many other browse species, may be inhibited by tannin precipitation, cell wall $\mathrm{N}$ (ADF-N), and nonprotein $\mathrm{N}$ (Barnes et al. 1991a; Forbes et al. 1995).

We investigated the effects of tannin on apparent $\mathrm{N}$ digestibility. Robbins et al. (1987) formulated an equation to predict digestible protein from crude protein and BSA precipitation values as follows:

$$
Z=-3.87+0.9283 X-11.82 Y
$$

where $Z$ is digestible protein $\left(\mathrm{g} \cdot 100 \mathrm{~g}\right.$ feed $\left.{ }^{-1}\right), X$ is crude protein content as a percent of dry matter, and $Y$ is BSA precipitation according to the Martin and Martin (1982) assay $\left(\mathrm{mg} \cdot \mathrm{mg}\right.$ forage dry matter $\left.^{-1}\right)$. This equation accurately predicted protein digestibility of fresh forages containing both condensed and hydrolyzable tannins (Hanley et al. 1992). All of our diets containing guajillo differed from the predicted values

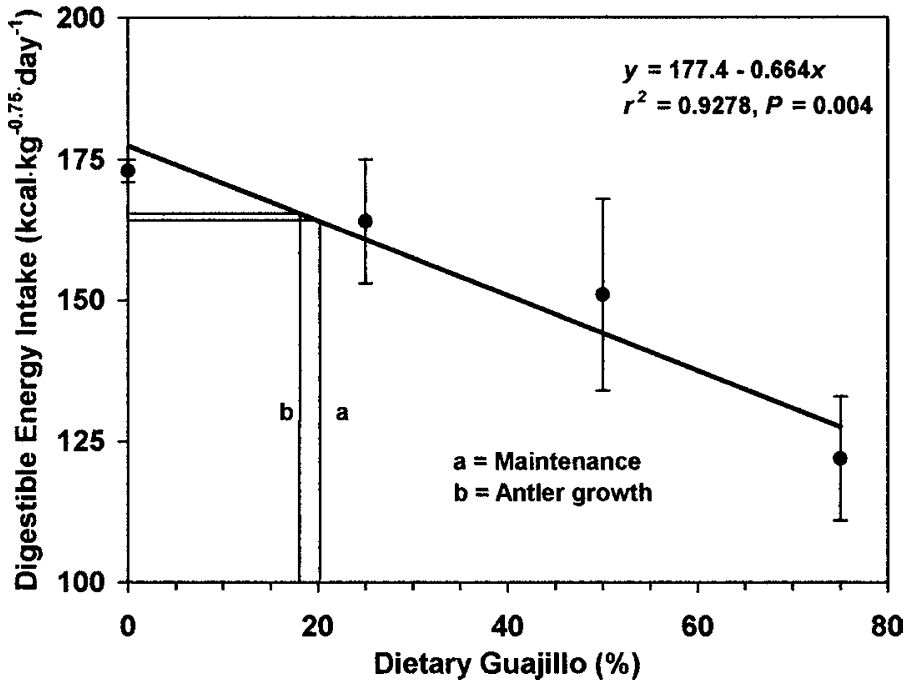

Figure 1. Digestible energy intake $( \pm \mathrm{SE})$ as a function of percent guajillo in diet for captive male white-tailed deer fed 4 diets during JulySeptember 1998 in Kingsville, Texas. Digestible energy requirements of free-ranging deer for maintenance (a; Robbins 1993) and for antler growth (b; Robbins 1983) were met with diets $<20 \%$ guajillo as displayed with horizontal and vertical lines.

(Fig. 3). Because observed protein digestibility was less than that predicted from protein concentration and protein precipitation from tannin, much of the $\mathrm{N}$ must be in forms not available to deer, such as cell wall or nonprotein $\mathrm{N}$ (Robbins et al. 1987; Barnes et al. 1991a).

We quantified the $\mathrm{N}$ content of the ADF to determine nondigestible cell wall N (Van Soest 1982). Values of ADF-N suggest that increasing dietary guajillo increased the amount

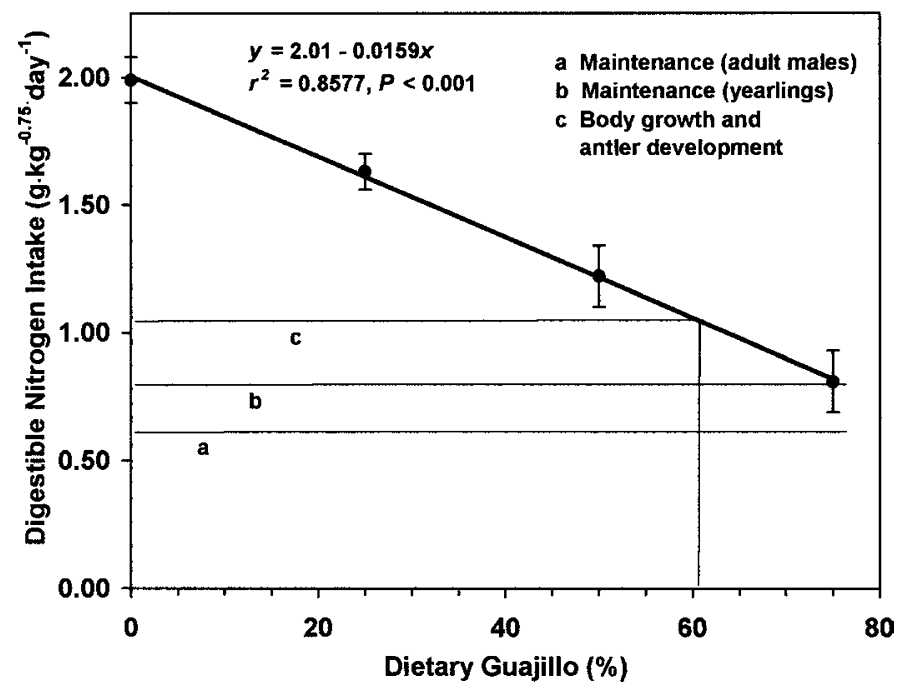

Figure 2. Digestible nitrogen intake $( \pm \mathrm{SE})$ as a function of percent guajillo in diet for captive adult male white-tailed deer fed 4 diets during July-September 1998 in Kingsville, Texas. Digestible nitrogen requirements of white-tailed deer for maintenance of adult males (a; Asleson et al. 1996), yearlings (b; Holter et al. 1979), and body growth and antler development (c; Asleson 1996) were met with diets $<60 \%$ guajillo as displayed with horizontal and vertical lines. 


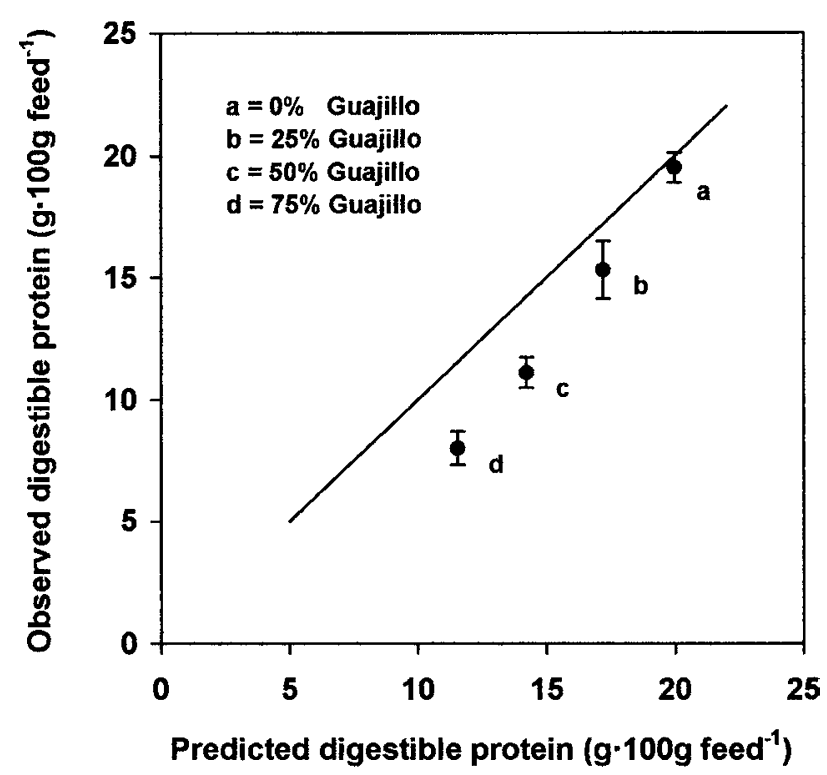

Figure 3. Relationship between observed and predicted digestible protein for adult male white-tailed deer fed 4 diets during JulySeptember 1998 in Kingsville, Texas. Observed values (mean \pm SD; $n=4)$ are from in vivo digestion trials; predicted values are from Robbins et al. (1987) equation. The line represents a 1:1 relationship.

of nondigestible fiber-bound $\mathrm{N}$, thus reducing the amount of digestible protein. Guajillo also contains numerous sources of nonprotein N (Clement et al. 1997), which would inflate crude protein values, but not contribute to actual amount of protein digested. This situation would further reduce the amount of $\mathrm{N}$ available to deer.

Urinary $\mathrm{N}$ excretion decreased with decreases in $\mathrm{N}$ intake. This relationship is consistent with other studies (Smith et al. 1975; Holter et al. 1979; Asleson et al. 1996). Urinary $N$ expressed as a function of digestible $\mathrm{N}$ intake has been used to determine the efficiency of digestible $\mathrm{N}$ use (Smith et al. 1975). The percent digestible $\mathrm{N}$ intake that was excreted in the urine was greater for the $75 \%$ guajillo diet than for the other diets. Not only was there less digestible $\mathrm{N}$ available with the $75 \%$ guajillo diet, but the available $\mathrm{N}$ was also used less efficiently. The apparent threshold effect for the digestible $\mathrm{N}$ intake excreted in the urine may be in response to tissue catabolism resulting from low metabolizable energy intakes and supported by the body mass loss for deer on the $75 \%$ guajillo diet.

Physiological processes within animals are dependent upon the maintenance of acid-base homeostasis. Foley and McArthur (1994) suggest that acid-base disturbances resulting from the absorption of plant chemicals reduce urinary urea recycling and diminish an animal's ability to concentrate urine. Urinary $\mathrm{N}$ concentration did not differ among diets. Additional evidence that guajillo initiated metabolic acidosis is lacking. Urine $\mathrm{pH}$ values did not differ among diets and were similar to those reported for control deer by DelGiudice et al. (1994) and Campbell and Hewitt (2000). In addition, urinary ammonium $\mathrm{N}$, which provides an index to the amount of acid neutralized in the body (Foley et al. 1995), did not differ among diets. Consequently, guajillo consumption does not appear to induce metabolic acidosis in deer. Similar to Hewitt and Kirkpatrick
(1997), our study does not support hypotheses suggesting that metabolic acidosis regulates the intake of all chemically defended plants (Foley et al. 1995).

Elevated urinary glucuronic acid excretion in the guajillo diets indicates that the guajillo diets contained absorbable plant chemicals that require conjugation. Conjugation occurs among the functional group of plant chemicals and endogenous molecules, such as glucuronic acid, glycine, or sulfate (Smith 1992). Urinary glucuronic acid excretion can also increase in response to protein deficiency (Woodcock and Wood 1971). In our study, it is unlikely that glucuronidation occurred in response to protein deficiency because all diets initiated a positive $\mathrm{N}$ balance. Urinary glucuronic acid excretion increased linearly with increased dietary guajillo. Hewitt and Kirkpatrick (1997) found that ruffed grouse (Bonasa umbellus L.) transferred conjugation activity from ornithine to glucuronides as the percent of mountain laurel (Kalmia latifolia L.) in the diet increased. Similarly, Nantoumé et al. (2001) observed elevated glucuronide activity within goats fed a $75 \%$ guajillo diet, but little variation in glucuronide excretion among diets of $0 \%, 25 \%$, and $50 \%$ guajillo. Because glucuronide activity in our study increased linearly with the guajillo content of the diet, it is unlikely that fluctuations in detoxification strategies involving glucuronides occurred. Analysis of additional conjugates would aid in the understanding of the detoxification strategies used by deer consuming guajillo diets.

Parker et al. (1999) concluded that the availability of digestible energy is likely the principle nutritional factor limiting deer populations. Our data concur. For all diets, digestible $\mathrm{N}$ intake rates greatly exceeded maintenance requirements for adult males (Asleson et al. 1996) and for yearlings (Holter et al. 1979). The protein requirement for body growth and antler development of adult males was met with diets of $<60 \%$ guajillo. Dietary differences for $\mathrm{N}$ balance suggest that increasing dietary guajillo reduces the amount of $\mathrm{N}$ available for productive processes that are dependent on $\mathrm{N}$ surpluses. It is unlikely that productive processes are limited by the reduction in available nitrogen, as evidenced by Figure 2. However, energy balance data suggest that maintenance and antler growth energy requirements are met only with diets containing $\leq 20 \%$ guajillo. We would expect energy deficits to be greater in female deer because of their elevated energy requirements associated with gestation and lactation (Sadleir 1982; Pekins et al. 1998).

Guajillo has traditionally been considered a good deer forage in southern Texas because of its abundance and high crude protein values (Davis 1990; Richardson 1990; Nantoumé et al. 2001). However, our data indicate dietary guajillo concentrations $>20 \%$ do not support the maintenance of white-tailed deer. Under drought conditions, guajillo may be important to white-tailed deer because it has large leaves, which allow for large bite sizes and high intake rates (Spalinger et al. 1997). High intake rates reduce the time spent foraging, allowing deer more time to search for forage of higher quality or to maximize thermoregulatory efficiency. From the perspective of white-tailed deer ecology and management, the primary function of guajillo and other browse species in southern Texas may be to facilitate maintenance of adult deer, which have fewer obligatory productive processes than young deer, during periods of drought. 


\section{ACKNOWLEDGMENTS}

We appreciate the assistance of C. Hensarling with the BSA assay. We thank F. Finley, J. Bonner, and P. Altheide for providing locations to collect guajillo. R. Brown, T. Fulbright, R. Warren, R. Lyons, and 4 anonymous reviewers provided helpful comments to drafts of this manuscript.

\section{LITERATURE CITED}

Asleson, M. A., E. C. Hellgren, and L. W. Varner. 1996. Nitrogen requirements for antler growth and maintenance in white-tailed deer. Journal of Wildlife Management 60:744-752.

Barnes, T. G., L. T. Blankenship, L. W. Varner, and J. F. Gallagher. 1991 a. Digestibility of guajillo for white-tailed deer. Journal of Range Management 44:606-610.

Barnes, T. G., L. W. Varner, L. H. Blankenship, and J. F. Gallagher. 1991b. Indigestible particulate passage in white-tailed deer. In: R. D. Brown [ed.]. The biology of deer. New York, NY: Academic Press, p 436-442.

Blumenkrantz, N., and G. Asboe-Hansen. 1973. New method for quantitative determination of uronic acids. Analytical Biochemistry 54:484-489.

Camp, B. J., H. R. Adams, and J. W. Dollahite. 1964. The chemistry of the toxic constituents of Acacia berlandieri. Annals of the New York Academy of Science 111:744-750.

Campbell, T. A., and D. G. Hewitt. 2000. Effect of metabolic acidosis on whitetailed deer antler development. Physiological and Biochemical Zoology 73 781-789.

Clement, B. A., C. M. Goff, And T. D. A. Forbes. 1997. Toxic amines and alkaloids from Acacia berlandieri. Phytochemistry 46:249-254.

Davis, E. 1990. Deer management in the South Texas Plains. Austin, TX: Texas Parks and Wildlife, Federal Aid Report Serial 27. Contribution of Federal Aid (P-R) Project W 125-R.

DelGiudice, G. D., L. D. Mech, and U. S. Seal. 1994. Nutritional restriction and acid base balance in white-tailed deer. Journal of Wildlife Diseases 30:247-253.

Foley, W. J., and C. McArthur. 1994. The effects and costs of ingested allelochemicals in mammals: an ecological perspective. In: D. J. Chivers, and P. Langer [eds.]. The digestive system in mammals: Food, form and function. Cambridge, UK: Cambridge University Press, p. 370-391.

Foley, W. J., S. McLean, AND S. J. CoRK. 1995. Consequences of biotransformation of plant secondary metabolites on acid-base metabolism in mammals-a final common pathway? Journal of Chemical Ecology 21:721-743.

Forbes, T. D. A., I. J. Pemberton, G. R. Smith, and C. M. Hensarling. 1995. Seasonal variation of two phenolic amines in Acacia berlandieri. Journal of Arid Environments 30:403-415.

Goering, H. K., and P. J. Van Soest. 1970. Forage analyses (apparatus, reagents, procedures and some applications). USDA Agricultural Handbook 379. $20 \mathrm{p}$.

Hanley, T. A., C. T. Robbins, A. E. Hagerman, and C. McArthur. 1992. Predicting digestible protein and digestible dry matter in tannin-containing forages consumed by ruminants. Ecology 73:537-541.

Hellgren, E. C., and W. J. Pitts. 1997. Sodium economy in white-tailed deer (Odocoileus virginianus). Physiological Zoology 70:547-555.

Hewitt, D. G., and R. L. KirkPatrick. 1997. Ruffed grouse consumption and detoxification of evergreen leaves. Journal of Wildlife Management 61: 129-139.

Holter, J. B., S. H. Smith, AND H. H. HAYes. 1979. Protein requirements of yearling white-tailed deer. Journal of Wildlife Management 43:872-879.

Hughes, H. G. 1982. Estimated energy, protein, and phosphorus balances of a south Texas white-tailed deer population [Ph.D. thesis]. College Station, TX: Texas A\&M University.

KUEHL, R. O. 1994. Statistical principles of research design and analysis. Belmont, CA: Duxbury Press. 686 p.

Martin, J. S., AND M. M. Martin. 1982. Tannin assays in ecological studies: lack of correlation between phenolics, proanthocyanidins and protein-precipitating constituents on mature foliage of six oak species. Oecologia 54: 205-211.

Mould, E. D., AND C. T. RobBins. 1981. Evaluation of detergent analysis in estimating nutritional value of browse. Journal of Wildlife Management 45: 937-947.

Nantoumé, H., T. D. A. Forbes, C. M. Hensarling, and S. S. Sieckenius. 2001. Nutritive value and palatability of guajillo (Acacia berlandieri) as a component of goat diets. Small Ruminant Research 40:139-148.

Parker, K. L., M. P. Gillingham, T. A. Hanley, and C. T. Robbins. 1999. Energy and protein balance of free-ranging black-tailed deer in a natural forest environment. Wildlife Monographs 143:1-48.

Pekins, P. J., K. S. Smith, AND W. W. Mautz. 1998. The energy cost of gestation in white-tailed deer. Canadian Journal of Zoology 76:1091-1097.

Remington, T. E. 1990. Food selection and nutritional ecology of blue grouse during winter [Ph.D. thesis]. Madison, WI: University of Wisconsin.

RichaRDSON, C. L. 1990. Factors affecting deer diets and nutrition. College Station, TX: Texas A\&M University.

RoBBINs, C. T. 1983. Wildlife feeding and nutrition. New York, NY: Academic Press.

RobBins, C. T. 1993. Wildlife feeding and nutrition. 2nd ed. New York, NY: Academic Press. 352 p.

Robilns, C. T., T. A. Hanley, A. E. Hagerman, 0. Hueljord, D. L. Baker, C. C. SchwaRTZ, AND W. W. MaUtz. 1987. Role of tannins in defending plants against ruminants: reduction in protein availability. Ecology 68:98-107.

SAdLEIR, R. M. F. S. 1982. Energy consumption and subsequent partitioning in lactating black-tailed deer. Canadian Journal of Zoology 60:382-386.

SAS INSTITUTE, INc. 1994. SAS/STAT guide for personal computers, version 6.10 . Cary, NC: SAS Institute Inc.

Schulman, R. S. 1992. Statistics in plain English. New York, NY: Chapman and Hall.

ScIFRES, C. J. 1980. Brush management, principles and practices for Texas and the Southwest. College Station, TX: Texas A\&M University Press. 360 p.

Sмıтн, G. S. 1992. Toxification and detoxification of plant compounds by ruminants: an overview. Journal of Range Management 45:25-30.

Smith, S. H., J. B. Holter, H. H. Hayes, and H. Silver. 1975. Protein requirements of white-tailed deer fawns. Journal of Wildlife Management 39:582-589.

Spalinger, D. E., S. M. Cooper, D. J. Martin, and L. A. Shipley. 1997. Is social learning an important influence on foraging behavior in white-tailed deer? Journal of Wildlife Management 61:611-621.

Van Soest, P. J. 1982. Nutritional ecology of the ruminant. Corvallis, OR: 0 \& B Books. 374 p.

VarneR, L. W., AND L. H. BLANKenship. 1987. South Texas shrubs: nutritive value and utilization by herbivores. Proceedings of the Symposium on Plant Herbivore Interactions. USDA Forest Service. USDA Forest Service General Technology Report INT-222. p 108-112.

VarneR, L. W., L. H. Blankenship, and G. W. Lynch. 1977. Seasonal changes in nutritive value of deer food plants in south Texas. Proceedings of the Annual Conference of the Southeastern Association of Fish and Wildlife Agencies 31:99-106.

VINES, R. A. 1984. Trees, shrubs, and woody vines of the Southwest. Austin, TX: University of Texas Press. $405 \mathrm{p}$.

Woodcock, B. G., AND C. C. Wood. 1971. Effect of protein-free diet on UDP glucuronyltransferase and sulphotransferase activities in rat liver. Biochemical Pharmacology 20:2703-2713. 